\title{
Economic losses due to clinical lameness in Kosovo dairy cattle
}

\author{
L. Ibishi, A. Musliu, B. Mehmedi, A. Rexhepi, C. R. Youngs and B. Behluli*
}

\begin{abstract}
The health of dairy cows is an important factor affecting the profitability of dairy farms worldwide, and lameness is regarded as one of the most costly dairy cattle diseases. The aim of this study was to estimate the economic cost of cow lameness among Kosovo dairy farms. Data collected from 56 dairy farms were analysed with a farm-level stochastic (Monte Carlo) simulation model to estimate the cost of lameness. Lameness-associated sources of economic loss examined within the model included: reduced milk production, treatment cost, discarded milk, reduced cow body weight, and premature culling. Results showed that prevalence of lameness among cows on Kosovo dairy farms ranged from $17 \%$ to $39 \%$. The average annual cost of lameness
\end{abstract}

was estimated at $€ 338.57$ per farm (or $€ 46.25$ per cow). Reduced milk production was the largest financial contribution to the cost of lameness ( $45 \%$ of total economic loss) followed by premature culling ( $31 \%$ of total economic loss). Discarded milk, reduced cow body weight, and cost of treatment each contributed approximately $8 \%$ to the total economic loss. These findings indicate that dairy farmers need to be more cognizant of the financial losses associated with lameness and should be encouraged to implement management strategies to reduce lameness as a means of enhancing farm profitability.

Key words: Dairy cattle; Health; Lameness; Economic cost

\section{Introduction}

The dairy sector remains one of the most promising sectors for economic development in Kosovo. The longstanding tradition of animal production, the climate, and the constant demand

for food have made livestock farming a vitally important contributor to the rural economy. After the war in Kosovo in 1999, development of the dairy sector was encouraged; however, progress

Lindita IBISHI, Msc student, Arben MUSLIU, Assoc. Professor, Department of Agro economy, University of Prishtina Faculty of Agriculture and Veterinary, Republic of Kosovo; Blerta MEHMEDI, DVM, PhD, teaching and research assistant, Department of Animal Reproduction, University of Prishtina, Faculty of Agriculture and Veterinary, Republic of Kosovo; Agim REXHEPI, DVM, PhD, Assoc. Professor, Department of Pathology, University of Prishtina, Faculty of Agriculture and Veterinary, Republic of Kosovo; Curtis R. YOUNGS, PhD, Full Professor \& M.E. Ensminger Endowed Chair of International Animal Agriculture, Iowa State University, USA; Behlul BEHLULI*, DVM, PhD, Assoc. Professor (Corresponding author, email: behlul.behluli@uni-pr.edu), Department of Animal Reproduction, University of Prishtina, Faculty of Agriculture and Veterinary, Republic of Kosovo 
has been less than desired. Dairy farms face numerous problems, such as small farm structure, fragmented farmland holdings, and low production efficiency (Bajrami, 2016), as well as limited technical knowledge of modern dairy farm management practices, including health management.

Lameness is the most important health problem in dairy cows in Kosovo, as elsewhere. Lameness can be defined as the clinical manifestation of painful disorders, mainly related to the locomotor system, resulting in impaired movement or deviation from normal gait or posture (Nuffel et al., 2015). Factors causing clinical lameness in dairy cattle are numerous and may include housing type, amount of free walking space, feeding regimen, genetic composition, herd size, social hierarchy of cows within a herd, overcrowding, climate, and hoof care practices (Mitev et al., 2012). The prevalence of lameness in dairy cattle was reported as 7\% in Denmark (Alban, 1995), 21\% in Canada (Solano et al., 2015), $31.6 \%$ in UK (Griffiths et al., 2018) and $2 \%$ to $54 \%$ in Hungary (Clarkson et al., 1996). Lameness is one of the most costly diseases in dairy animals; after infertility and mastitis, it has the most serious adverse economic impacts on dairy farms (Logue, 1997).

The economic losses resulting from lameness are related to decreased milk production, reduced cow body weight, premature culling from the herd, decreased reproductive performance, treatment costs (including the cost of milk discarded due to antibiotic therapy), and death (Warnick et al., 2001). Lameness affects the welfare of dairy herds by limiting productivity (Sadiq et al., 2017), and losses of milk production in lame cows can vary between $5 \%$ and $30 \%$ depending on clinical manifestation of the disease (Simbirtsev and Terehov, 1982). Unfortunately, higher yielding cows are more likely to develop lameness and suffer a greater reduction in milk production (Green et al., 2002). Clinical lameness frequently results in premature culling of animals from the herd, and it is the third most common reason for early culling, after mastitis and reproductive disorders (Esslemont and Kossaibati, 1997). In addition to direct economic losses, lameness also causes indirect economic losses due to factors such as increased labour costs. Both direct and indirect losses negatively impact farm income (Mitev et al., 2012)

The aim of this study was to estimate the cost of lameness among dairy farms in Kosovo. Given that the dairy sector is an important economic and social contributor in Kosovo, quantifying the magnitude of financial losses associated with lameness is important to provide fact-based incentive for change. This is the first study of its kind to be conducted in Kosovo, and the results are expected to be of direct relevance to other dairy cattle producing regions of the world.

\section{Materials and Methods}

\section{Data collection}

The Republic of Kosovo is situated in Southeast Europe. Based on differences in topography, the country is divided into two large regional geographic units (Figure 1): Rrafshi Kosovo (northern and eastern part) and the Dukagjini plain (western and southern part).

Visits to 56 commercial dairy farms with over 10 cows/farm were conducted from January 2017 to December 2017. Data collected included milk production, milk sales price, prevalence of lameness, productivity decrease associated with lameness, treatment costs, economic losses from the reduction of cow body weight, and economic losses from premature culling. The duration of clinical lameness, health condition of cows after treatment, and discarded milk period were also recorded. Data were 
collected with cooperation of the farm veterinarians.

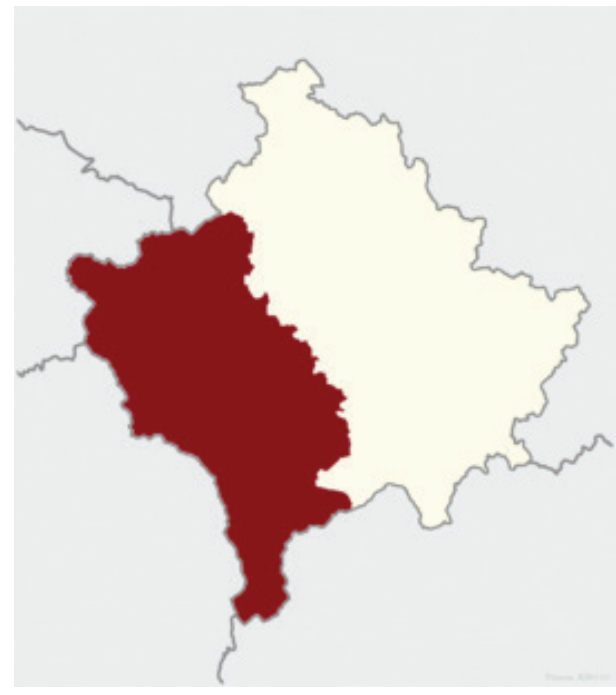

Figure 1. Study area included dairy farms in the Dukagjini region (maroon) and Rrafshi and Kosovës region (pale yellow). Photo credit: Wikipedia

\section{Simulation model}

A stochastic (Monte Carlo) simulation model was developed (using Vose Software) to estimate the total cost of lameness in the studied herds. The five input parameters for the simulation model were the costs of reduced milk production, treatment, discarded milk, reduced cow body weight, and premature culling.

Cost of reduced milk production $\left(C P R_{m}\right)$ : When assessing the quantity of milk loss due to lameness, different calculation approaches can be used (Ózsvári, 2017). Milk loss was estimated by comparing lame cows before and after treatment to cows in the herd that did not exhibit clinical lameness (Warnick et al., 2001; Hernandez et al., 2002).

In this study, the cost of reduced milk production $\left(\mathrm{CPR}_{\mathrm{M}}\right)$ was calculated per lactation on a within cow basis of lame cows in the herd according to the total loss in earnings (the difference of milk production before $\left(\mathrm{Pb}_{\mathrm{i}}\right)$ and after lameness $\left(\mathrm{Pa}_{\mathrm{i}}\right)$, multiplied by the price of milk $\left(\mathrm{Pm}_{\mathrm{i}}\right)$ as shown in equation 1.

$C P R_{M}=\left(P b_{i}-P a_{i}\right) \times P m_{i}$

Treatment cost (TC): The cost of lameness treatment included the fee for professional veterinary services and the cost of drugs used during treatment. Treatment cost depended on the type, duration, and severity of lameness. Treatment cost (TC) was the sum of the cost of veterinary service $\left(C V_{s}\right)$ and the cost of drugs $\left(C R_{x}\right)$ shown in equation 2 .

$T C=C V_{S}+C R_{x}$

Cost of discarded milk (CDm): If lame cows are treated with antibiotics, their milk must be discarded in accordance with the labelled milk discard period. Moru et al. (2018) estimated the cost of discarded milk by multiplying the discarded milk per cow $\left(\mathrm{Dm}_{\mathrm{i}}\right)$ by the price of milk $\left(\mathrm{Pm}_{\mathrm{i}}\right)$ as shown in equation $3 a$.

$C D m=\sum_{i=1}^{n} D m_{i} x P m_{i}$

We modified this equation to account for differences in the approved milk discard period $\left(\mathrm{CP}_{\mathrm{RX}}\right)$ among different antibiotics. Our calculation of the cost of discarded milk $\left(\mathrm{CD}_{\mathrm{M}}\right)$ is shown in equation $3 b$.

$C D_{M}=D m_{i} \times P m_{i} \times C P_{R X}$

Cost of reduced cow body weight $\left(C R_{b w}\right)$ : Farmers were asked how much body weight $(\mathrm{kg})$ their cows lost during the period of lameness, and that weight loss $\left(\mathrm{WL}_{\mathrm{i}}\right)$ was multiplied by the price of meat in the market received by farmers at the abattoir $\left(\mathrm{Pm}_{\mathrm{i}}\right)$ as shown in equation 4 .

$C R_{b w}=W L_{i} \times P m_{i}$ 
Cost of premature culling (CPC): The cost of premature culling was calculated (Ózsvári, 2017) as the margin of the slaughter value of the cow culled because of lameness (SVc) and the cost of replacement heifers (Crh) as shown in equation 5.

$C P C=C r h-S V C$

Herd cost of lameness (HCL): Because all contributing cost variables were estimated at the herd level, the total herd cost of lameness was estimated as the sum of the cost variables (Moru et al., 2018) as shown in equation 6.

$H C L=C R P_{M}+T C+C D_{M}+C R b w+C P C$

Cow cost of lameness (CCL): To estimate the per cow cost associated with lameness, the herd cost of lameness (HCL) of each farm was divided by the number of cases of lameness $\left(\mathrm{L}_{\text {casse }}\right)$ observed on that farm as shown in equation 7 .

$C p c=\frac{H C L}{L_{\text {Cases }}}$

\section{Sensitivity analysis}

A sensitivity analysis (Saltelli et al., 2008) was conducted on the input parameters that influenced the cost of lameness. This analysis was performed to assess the magnitude of impact of each of these parameters on the overall cost of lameness.

\section{Data analysis}

For all cases of lameness on the study farms, parameters (reduced milk production, treatment cost, discarded milk, reduced cow body weight, premature culling) were analysed using one-way ANOVA. The aim was to assess whether lameness had a negative effect on farm income by decreasing the parameters, and the F statistic was calculated (Johnson \& Bhattacharyya, 2010) as shown in equation 8 .
$F=\frac{\sum n j(\overline{X j}-\bar{X})^{2} /(k-1)}{\sum \sum(X-\bar{X} j)^{2} /(N-k)}$

The correlation between lameness and farm income was also investigated. During farm visits, we monitored the health condition of cows exhibiting clinical signs of lameness during and after medical treatment. We tested the impact of veterinary drugs on the improvement of lameness after treatment by using the t-test. We tested two hypotheses:

H0: The difference between the mean of the two cases is equal to zero $\left(\mu_{\text {diff }}=0\right)$ and lameness treatment was not successful.

H1: The difference between the mean of the two cases is different from zero $\left(\mu_{\text {diff }} \neq 0\right)$ and lameness treatment was successful.

The equation used for this case (Johnson and Bhattacharyya, 2010) is shown in equation 9:

$t=\frac{\bar{X} 1-\overline{X 2}}{\sqrt{\frac{\mathrm{s}_{l}^{2}+\mathrm{s}_{2}^{2}-2 \rho \mathrm{s}_{l} \mathrm{~s}_{2}}{n}}}$

\section{Results and discussion}

Lameness on dairy farms is a serious health problem that has negative impacts in the economic performance of dairy farms in Kosovo. Our study focused on 56 farms with more than 10 cows per farm (mean: 26.25 cows; range: 10-70 cows). Among the 1470 cows included in the study, lameness was observed in 410 cows $(27.9 \%)$, and there was an average of $7.32( \pm 5.49)$ lameness cases per farm. The prevalence of lameness within individual farms varied from $17 \%$ to $39 \%$.

\section{Costs of lameness}

The average per farm decrease in milk production associated with lameness was $568.2 \pm 165.9 \mathrm{~kg}$. During the time when cows were not affected by lameness, they produced $1.86 \pm 0.54 \mathrm{~kg}$ more milk 
Table 1. Sources of annual economic losses (in EUR) associated with bovine lameness among 56 dairy farms in Kosovo

\begin{tabular}{|l|c|c|}
\hline Sources of Losses & Per farm & Per cow \\
\hline Reduced milk production & 153.83 & 21.01 \\
\hline Premature culling & 104.54 & 14.28 \\
\hline Discarded milk & 27.66 & 3.78 \\
\hline Reduced cow body weight & 26.56 & 3.63 \\
\hline Treatment cost & 25.98 & 3.55 \\
\hline Total cost & 338.57 & 46.25 \\
\hline
\end{tabular}

per day than when they were affected by lameness. The average quantity of milk discarded due to treatment of lame cows with antibiotics was $96.9 \pm 28.03 \mathrm{~kg}$. The average length of the milk discard period due to antibiotic treatment of lactating cows exhibiting clinic lameness was $6 \pm 0.9$ days.

The estimated annual average annual cost of lameness in the 56 dairy farms we studied (Table 1) was $€ 338.57$ per farm (or $€ 46.25$ per cow).

Figure 2 depicts the percentage contribution of each source of per farm economic loss attributed to lameness in dairy cattle. Reduced milk production gave the greatest contribution to the costs of lameness (45\% of total economic loss) followed by premature culling (31\% of total economic loss). Discarded milk, treatment cost, and reduction on cow body weight each contributed approximately $8 \%$ to the total economic loss.

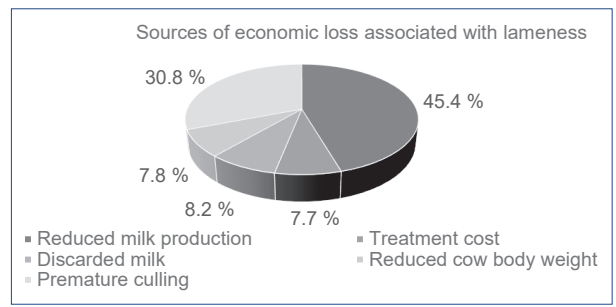

Figure 2. Sources of economic loss associated with lameness

\section{Sensitivity analysis}

The results of the sensitivity analysis (Figure 3) show that reduced milk production of lame dairy cows is the most important contributor to the total cost of lameness on a per farm basis. Analysis revealed that a $10 \%$ increase in milk production would elevate the lameness cost from $€ 338.57$ to $€ 405.31$ per farm, whereas a $10 \%$ decrease in milk output would diminish the cost of lameness from $€ 338.57$ to $€ 272.37$. Similarly, a $10 \%$ rise in premature culling would increase the cost of lameness from $€ 338.57$ to $€ 378.34$ per case, but a $10 \%$ decrease in premature culling would reduce lameness cost from $€ 338.57$ to $€ 309.76$. A change of $\pm 10 \%$ of discarded milk and reduced cow body weight would vary the cost of lameness from $€ 321.56$ to $€ 353.53$ and $€ 327.79$ to $€ 351.94$, respectively. Treatment cost had the least effect on total lameness cost; a 10

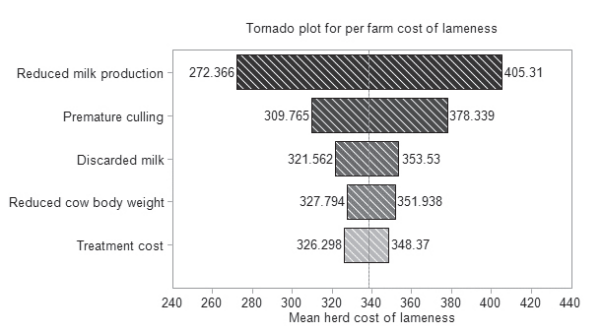

Figure 3. Tornado plot showing economic effect (in Euro) of each of five contributors to the per farm cost of bovine lameness among 56 dairy farms in Kosovo 
Table 2. The impact on farm income of various contributors to bovine lameness on 56 dairy farms in Kosovo

\begin{tabular}{|c|c|c|c|c|c|}
\hline & & df & MS & $F$ & $P$ \\
\hline $\begin{array}{l}\text { Reduced milk } \\
\text { production }\end{array}$ & $\begin{array}{l}\text { Between Groups } \\
\text { Within Groups } \\
\text { Total }\end{array}$ & $\begin{array}{l}17 \\
38 \\
55\end{array}$ & $\begin{array}{l}33218653.22 \\
1643391.626\end{array}$ & 20.213 & $* * *$ \\
\hline Premature culling & $\begin{array}{l}\text { Between Groups } \\
\text { Within Groups } \\
\text { Total }\end{array}$ & $\begin{array}{l}17 \\
38 \\
55\end{array}$ & $\begin{array}{l}3779.829 \\
3020.102\end{array}$ & 1.252 & NS \\
\hline Discarded milk & $\begin{array}{l}\text { Between Groups } \\
\text { Within Groups } \\
\text { Total }\end{array}$ & $\begin{array}{l}17 \\
38 \\
55\end{array}$ & $\begin{array}{c}113167.819 \\
2818.593\end{array}$ & 40.150 & $* * *$ \\
\hline $\begin{array}{l}\text { Reduced cow body } \\
\text { weight }\end{array}$ & $\begin{array}{l}\text { Between Groups } \\
\text { Within Groups } \\
\text { Total }\end{array}$ & $\begin{array}{l}17 \\
38 \\
55\end{array}$ & $\begin{array}{c}204388.495 \\
11447.320\end{array}$ & 20.731 & $* * *$ \\
\hline Treatment cost & $\begin{array}{l}\text { Between Groups } \\
\text { Within Groups } \\
\text { Total }\end{array}$ & $\begin{array}{l}17 \\
38 \\
55\end{array}$ & $\begin{array}{c}84819.714 \\
1301.601\end{array}$ & 65.166 & $* * *$ \\
\hline
\end{tabular}

Table 3. Correlation between bovine lameness and farm income on 56 dairy farms in Kosovo

\begin{tabular}{|c|c|c|c|}
\hline & & Lameness & Farm incomes \\
\hline Lameness & $\begin{array}{l}\text { Person Correlation } \\
\text { Sig. (2-tailed) } \\
\text { N }\end{array}$ & $\begin{array}{c}1 \\
56\end{array}$ & $\begin{array}{l}0.760 * * \\
* * *\end{array}$ \\
\hline
\end{tabular}

Table 4. The impact of veterinary drugs on the improvement of the health condition of cows with lameness

\begin{tabular}{|c|c|c|c|c|c|c|}
\hline & & & $\begin{array}{c}\text { Paired } \\
\text { Differences }\end{array}$ & & & \\
\hline & Mean & Std. Deviation & $\begin{array}{l}\text { Std. Error } \\
\text { Mean }\end{array}$ & $\mathrm{t}$ & $d f$ & $P$ \\
\hline $\begin{array}{l}\text { Milk production during } \\
\text { lameness minus } \\
\text { milk production after } \\
\text { treatment }\end{array}$ & -0.79929 & 1.42521 & 0.19045 & -4.197 & 55 & $* * *$ \\
\hline
\end{tabular}


$\%$ increase or reduction in treatment cost would change the cost of lameness from $€$ 338.57 to $€ 348.37$ or $€ 326.30$, respectively.

\section{Impact of lameness on farm income}

Using the one-way ANOVA, we evaluated whether clinical lameness had a negative effect on farm income through each of the five main factors that contributed to the cost of lameness (reduced milk production, increased risk of premature culling, discarded milk, decreased cow body weight, and treatment cost). The results are shown in Table 2.

There was a strong positive correlation between the incidence of lameness and farm income (Table 3).

Another statistical analysis was conducted to test the impact of veterinary treatment (antibiotics) on the improvement of lameness. Milk production of lame cows was measured during lameness and after antibiotic treatment. The results are presented in Table 4.

The t-test evaluated milk production before and after treatment of lame cows. The observed difference $(P<0.001)$ in milk production during lameness and after treatment provides high confidence that the difference in milk production due to treatment is not zero $(\mu d \neq 0)$. From this, we conclude that lameness treatment was successful.

To our knowledge, this study is the first to estimate the per farm cost of lameness in dairy farms in Kosovo. The results indicated that lameness is a serious health problem that has a negative impact $(€ 338.57$ per farm; $€$ 46.25 per cow) on the economic viability of dairy farms in Kosovo. Lameness is a production-limiting disease of dairy cattle (Kossaibati and Esslemont, 1997), and thus it is not surprising that lameness reduced farm income in this study.

Numerous reports have described the problem of lameness in dairy cattle in Kosovo; however, none of them specifically examined the effect of lameness on farm profitability. Poor hygienic conditions, prevalent use of tiestall management systems, and lack of space for unrestricted mobility of cows (Zhitia, 2017) make lameness the most important health problem on Kosovo dairy farms. The prevalence of this health condition on the farms we studied ranged from $17 \%$ to $39 \%$.

Although one might hypothesize that farms with a higher incidence of lameness would have reduced farm income, the correlation analysis in the present study revealed a strong positive correlation ( $\mathrm{r}$ $=0.760 ; P<0.001$ ) between lameness and farm income. Farms with the highest incidence of lameness had higher levels of milk production per cow (and hence higher gross farm income). This result (positive correlation between level of milk production per cow and incidence of lameness) agrees with several previously published reports (Hernandez et al., 2002). A majority of previous studies showed that lameness reduced milk yield, reduced cow live body weight and increased premature culling of cows from the herd (Booth et al., 2004; Amory et al., 2008). All these factors caused direct economic losses to the farm. Lameness also caused indirect economic losses to the dairy farms through increased treatment costs, higher labour costs, and discarded milk (due to antibiotic treatment). In this study, lameness reduced milk production, increased the amount of discarded milk, elevated health treatment costs and reduced live weight (all at $P<0.001$ ). Reduced milk production contributed the most $(45.4 \%)$ to the total per farm cost of lameness, followed by premature culling (30.8\%) and discarded milk (8.2\%). Interestingly, premature culling of cows from the herd due to lameness was not significant $(P$ $>0.05)$. This latter result may have been obtained because the difference in the 
purchase price of replacement heifers is not substantially higher than the salvage value of cull cows. Alternatively, this result could be explained because there is very little price discrimination in the marketplace between "young" cull cows and "old" cull cows.

In this study, lameness reduced milk yield by $568 \pm 166 \mathrm{~kg}$ over a 305-day lactation period. Amory et al. (2008) reported that lame dairy cows produced between 370 and $570 \mathrm{~kg}$ less milk per lactation. Green et al. (2002) stated that cows with clinical lameness exhibited a 160 to $550 \mathrm{~kg}$ decrease in milk yield per lactation compared with cows not affected by lameness. Cows unaffected by lameness during their lifetime produced $1.12 \mathrm{~kg}$ more milk per milking than cows that experienced any form of lameness. In cows that are closely monitored, it is possible to document decreased milk yields even before the clinical expression of lameness (Ekiz, 2006). This research group reported a $203 \mathrm{~kg}$ reduction in 305day lactation milk yield due to dairy cow lameness (Koçak and Ekiz, 2006).

When a cow shows clinical signs of lameness, it may be treated with antibiotics. In practice, it is usually only the more severely lame cows that are treated, though the treatment approach can vary widely based on the type and severity of foot lesions (Ózsvári, 2017). During farm visits, we monitored the health condition of cows with lameness during and after medical treatment. Using a paired t-test we showed that the lameness treatments were successful overall. The cost associated with lameness in this study was $€ 338.57$ per farm (or $€ 46.25$ per cow). The number of commercial dairy farms in Kosovo is 4,238 (MAFRD, 2016). Based on the average prevalence of clinical lameness in our study of $27.9 \%$ (410 cases among 1470 cows), we predicted the total economic losses associated with clinical lameness across all commercial dairy farms in Kosovo to be $€ 401,760.70$ for the year 2017. It should be recognized, however, that the economic costs associated with lameness differ across farms, across people responsible for animal treatment, across underlying causes and types of lameness, and across countries (Olechnowicz and Jaskowski, 2011).

Enting et al. (1997) calculated the costs of lameness in the Netherlands using a partial budget model. The total costs associated with lameness were NLG 229.79 \pm 103.30 (equivalent to USD $132.43 \pm 59.53$ ) per cow per year. In a study conducted in England, Kossaibati and Esslemont (1997) reported total farm costs of $£ 246.22$ (USD 421.53) for average lameness cases, $£ 212.60$ (USD 363.97) for digital lameness cases, $£$ 112.80 (USD 193.11) for interdigital lameness cases, and $£ 391.80$ (USD 670.76) for sole ulcer cases. In Hungary, the average annual cost of lameness per cow was $€ 61.60$ and $€ 320.20$ per farm (Ózsvári et al., 2007).

The economic conditions affecting dairy farms are undergoing a variety of changes in Kosovo (Bytyqi et al., 2014). The same is likely true in other dairy-producing regions of the world. The dairy sector is one of the most promising sectors that can contribute favourably to Kosovo's economic and social development; thus, there is a strong need to recognize and address problems of the dairy sector. The results of this study confirmed that dairy farms in Kosovo, as in other countries, have some problems regarding the health and welfare of their cows. The results also quantified, for the first time, the significant economic losses caused by lameness in dairy farms in Kosovo. The issue of cow health is directly related to cow productivity, and lameness therefore has an impact on the current and future profitability of any dairy farm (Otte and Chilonda, 2000). 


\section{Conclusions}

Quantification of the economic losses associated with lameness is important not only to assess the current situation, but also to provide a basis from which to answer questions such as: (1) Can financial losses be limited if diseases occur? (2) In what way and to what extent can the risk of disease be diminished? and (3) How much economic loss can be avoided, and what efforts and costs are involved in doing so? (Dijkhuizen and Morris, 1997).

Dairy cattle farmers in Kosovo (and elsewhere) should pay more attention to important management parameters such as a healthy and balanced diets for cows, reproductive performance, hygienic conditions, housing type (e.g., free stall versus tie stall), herd size, free space for cows to walk, and health protocols. Outstanding management practices at the farm level would improve farm incomes and bolster the entire milk supply chain in the country.

\section{References}

1. ALBAN, L. (1995): Lameness in Danish dairy cows: frequency and possible risk factors. Prev. Vet. Med. 22, 213-225.

2. AMORY, J. R., Z. E. BARKER, J. L. WRIGHT, S. A. MASON, R. W. BLOWERY, and L. E. GREEN (2008): Associations between sole ulcer, white line disease and digital dermatitis and the milk yield of 1824 dairy cows on 30 dairy cow farms in England and Wales from February 2003-November 2004. Prev. Vet. Med. 83, 381-391.

3. BAJRAMI, E. (2016): "Evaluation of Agricultural Policy in the Dairy Sector in Kosovo and Efficiency Analysis at the Farm Level". Arkansas: University of Arkansas, Fayetteville. Retrieved from https:// scholarworks.uark.edu/etd/1720

4. BOOTH, C. J., L. D. WARRICK, Y. T. GROHN, D. O. MAIZON, C. L. GUARD and D. JANSEEN (2004): Effect of lameness on culling in dairy cows. J. Dairy Sci. $87,4115-4122$.

5. BYTYQI, H., M. THAQI, F. HOXHA, A. MISINI, B. HAXHIJA, H. MEHMETI and V. E. CABRERA (2014): Economic Assessment of Dairy Farm Production in Kosovo. Vienna: International Farming Systems Association (IFSA) Europe.

6. CLARKSON, M. J., D. Y. DOWNHAM, W. B. FAULL, J. W. HUGHES, F. J. MANSON, J. B.
MERRIT and W. R. WARD (1996): Incidence and prevalence of lameness in dairy cattle. Vet. Rec. 138, 563-567.

7. DIJKHUIZEN, A. A. and R. S. MORRIS (1997): Animal health economics : principles and applications. Sydney: University of Sydney, PostGraduate Foundation in Veterinary Science.

8. ENTING, H., D. KOOIJ, A. DIJKHUIZEN, R. HUIRNE and E. NOORDHUIZEN-STASSEN (1997): Economic losses due to clinical lameness in dairy cattle. Livest. Prod. Sci., 49, 259-267.

9. ESSLEMONT, R. J. and M. A. KOSSAIBATI (1997): Culling in 50 dairy herds in England. Vet. Rec. 140, 36-39.

10. GREEN, L., V. HEDGES, Y. SCHUKKEN, R. BLOWEY and A. PACKINGTON (2002): The Impact of Clinical Lameness on the Milk Yield of Dairy Cows. J. Dairy Sci. 85, 2250-2256.

11. GRIFFITHS, B. E., D. G. WHITE and G. OIKONOMOU (2018): A Cross-Sectional Study Into the Prevalence of Dairy Cattle Lameness and Associated Herd-Level Risk Factors in England and Wales. Front. Vet. Sci. 5: 65. doi: 10.3389/ fvets.2018.00065

12. HERNANDEZ, J., J. K. SHEARER and D. W. WEBB (2002): Effect of lameness on milk yield in dairy cows. JAVMA, 220, 640-644.

13. JOHNSON, R. A. and G. K. BHATTACHARYYA (2010): Statistics Principles and Methodes. Hoboken, NJ, The United States of America: Laserwords Private Limited.

14. KOCAK, Ö. and B. EKIZ (2006): The Effect of Lameness on Milk Yield in Dairy Cows. Acta Vet. Brno, 75, 79-84.

15. KOSSAIBATI, M. and R. ESSLEMONT (1997): The costs of production diseases in dairy herds in England. Vet. J. 154, 41-51.

16. LOGUE, D. N. (1997): Productivity, management and disease in dairy cattle. Bovine Practitioner 31, 51-55.

17. MAFRD (2016): Green Report. Prishtina: Ministry of Agriculture, Forestry and Rural Development.

18. MITEV, J., T. PENEV, N. VASILEV, T. MITEVA, Z GERGOVSKA and K. UZUNOVA (2012): Effect of lameness on some productive traits and health status of cows in dairy cattle farms. Trakia J. Sci. 10, 85-91.

19. MORU, N. H., J. U. UMOH, B. V. MAIKAI, P. P. BARJE and P. AMUTA (2018): Milk yield losses and cost of clinical mastitis in Friesian $\times$ Bunaji crossbred dairy cows in Zaria, Nigeria. Sokoto J. Vet. Sci. 16, 28-34.

20. NUFFEL, A. V., I. ZWERTVAEGHER, L. PLUYM, V. S. WEYENBERG, M. V. THORUP, M. PASTELL and W. SAEYS (2015): Lameness Detection in Dairy Cows: Part 1. How to Distinguish between NonLame and Lame Cows Based on Differences in Locomotion or Behavior. Animals 5, 838-860.

21. OLECHNOWICZ, J. and J. M. JASKOWSKI (2011): Reasons for culling, culling due to lameness, and economic losses in dairy cows. Medycyna Wet., 67, 618-621. 
22. OTTE, M. J. and P. CHILONDA (2000); Animal Health Economics: an Introduction. Rome: Animal Production and Healthy Division (AGA), FAO,. Retrieved from http://www.fao.org/ag/againfo/ resources/fr/publications/agapubs/pproc01.pdf

23. ÓZSVARI, L., R. BARNA and L. VISNYEI (2007): Economic losses due to bovine foot diseases in large-scale Holstein-friesian dairy herds. Magy Állatorv Lapja, 129, 23-28. (in Hungarian).

24. SADIQ, M. B., S. RAMANOON, W. S. MOSSADEQ, R. MANSOR and S. SYED-HUSSAIN (2017): Association between Lameness and Indicators of Dairy Cow Welfare Based on Locomotion Scoring, Body and Hock Condition, Leg Hygiene and Lying Behavior. Animals 7, 79.

25. SAltelli, A., M. RATTO, T. ANDRES, T. et al. (2008). Global Sensitivity Analysis. The Primer. Chichester: TJ International.
26. SIMBIRTSEV, P. F. and I. F. TEREHOV (1982): Hoof diseases in cows and bulls of farmers: Important problems of obstetric gynecological and surgical pathology of farm animals. Proceedings of Scientific Works, pp. 59-64.

27. SOLANO, L., H. W. BARKEMA, E. A. PAJOR, S. MASON, S. J. LEBLANC, J. C. HEYERHOFF and K. ORSEL (2015): Prevalence of lameness and associated risk factors in Canadian HolsteinFriesian cows housed in freestall barns. J. Dairy Sci. 98, 6978-6991.

28. WARNICK, L. D., D. JANSSEN, C. L. GUARD and Y. GROHN (2001): The Effect of Lameness on Milk Production in Dairy Cows. J. Dairy Sci. 84, 1988-1997.

29. ZHITIA, E. (2017): Animal welfare assessment and potential strategies to improve dairy cattle welfare in Kosovo. Vienna: University of Natural Resources and Life Sciences.

\section{Ekonomski gubitci prouzročeni zbog kliničke hromosti muzne stoke s Kosova}

Lindita IBISHI, Msc, student, dr. sc. Arben MUSLIU, izvanredni profesor, Odsjek za agroekonomiju, Sveučilište u Prištini, Agronomski i Veterinarski fakultet, Republika Kosovo; Blerta MEHMEDI, dr. med. vet., asistentica u nastavi i istraživanju, Odjel za reprodukciju životinja, Sveučilište u Prištini, Poljoprivredni i Veterinarski fakultet, Republika Kosovo; dr. sc. Agim REXHEPI, dr. med. vet., izvanredni profesor, Odsjek za patologiju, Sveučilište u Prištini, Poljoprivredni i Veterinarski Fakultet, Republika Kosovo; dr. sc. Curtis R. YOUNGS, redoviti profesor i M.E. Ensminger katerdra za međunarodnu poljoprivredu životinja, Državno Sveučilište Iowa, SAD; dr. sc. Behlul BEHLULI, dr. med. vet, izvanredni profesor, Odjel za reprodukciju životinja, Sveučilište u Prištini, Poljoprivredni i Veterinarski fakultet, Republika Kosovo

Zdravlje muznih krava važan je faktor koji utječe na profitabilnost mliječnih farmi širom svijeta, a hromost se smatra jednom od najskupljih bolesti mliječne stoke. Cilj ove studije bio je procijeniti ekonomske gubitke hromosti krava između farmi mlijeka s Kosova. Podatci prikupljeni na 56 farmi mliječnih krava analizirani su stohastičkim modelom na razini farme (Monte Carlo) kako bi se procijenio trošak hromosti. Izvori ekonomskog gubitka povezani s hromošću ispitivani su u okviru modela koji uključuje: smanjenu proizvodnju mlijeka, troškove liječenja, bačeno mlijeko, smanjenu tjelesnu težinu krave i preuranjeno izlučivanje. Rezultati su pokazali da se prevalencija hromost među kravama na Kosovskim mliječnim farmama kreće od $17 \%$ do $39 \%$. Prosječni godišnji trošak hromosti procijenjen je na 338,57 eura po farmi (ili 46,25 eura po kravi). Smanjena proizvodnja mlijeka predstavljala je najveći financijski doprinos troškovima hromosti (45\% ukupnog ekonomskog gubitka), nakon čega je uslijedilo prerano izlučivanje krava (31 \% ukupnog ekonomskog gubitka). Bačeno mlijeko, smanjena tjelesna težina krave i troškovi liječenja iznose približno 8 $\%$ od ukupnog ekonomskog gubitka. Ove spoznaje ukazuju na to da mljekari trebaju biti svjesniji o financijskim gubitcima povezanim s hromošću i treba ih poticati da provode strategije upravljanja za smanjenje hromosti kao sredstvo za povećanje profitabilnosti farmi.

Ključne riječi: mliječne krave, zdravlje, hromost, ekonomski trošak 